\title{
Competition, transmission and bank pricing policies: Evidence from Belgian loan and deposit markets
}

\author{
Ferre De Graeve *, Olivier De Jonghe, Rudi Vander Vennet \\ Ghent University, Wilsonplein 5D, 9000 Ghent, Belgium \\ Received 6 July 2005; accepted 17 March 2006 \\ Available online 14 August 2006
}

\begin{abstract}
This paper addresses the pass-through from market interest rates to retail bank interest rates. The paper advocates a heterogeneous approach and applies it to the Belgian banking market. A substantial proportion of the heterogeneity in bank pricing policies can be explained by the bank lending channel and the relative market power hypothesis. The results also suggest that the long-term passthrough is typically less than one-for-one, rejecting the completeness hypothesis. While there is no convincing evidence for asymmetry in retail rates, large deviations from equilibrium mark-ups are faster reduced than small deviations. Overall, conditions for corporate loans are more competitive compared to consumer loans. Demand and savings deposits have, by far, the most rigid prices.
\end{abstract}

(c) 2006 Elsevier B.V. All rights reserved.

JEL classification: E43; E52; G21; L11

Keywords: Retail bank interest rates; Pass-through; Heterogeneity; Panel cointegration; Bank lending channel

\section{Introduction}

This paper introduces heterogeneity in quantifying the pass-through from market interest rates to retail bank interest rates. From a macro-economic perspective, understanding the behaviour of retail interest rates is crucial. According to the traditional interest rate

\footnotetext{
* Corresponding author. Tel.: +32 926478 93; fax: +329264 8995 .

E-mail address: ferre.degraeve@ugent.be (F. De Graeve).
} 
channel of monetary policy transmission, policy rates have a one-for-one effect on interest rates upon which agents base their decisions. Much of the research in the pass-through literature aims to test that assumption, the so-called completeness hypothesis. Another assumption implicit in the money view of policy transmission is that there are no distributional effects across banks. According to the credit view, however, differences in banks' financial structure entail heterogeneities in bank behaviour. From a micro-economic perspective, the pass-through sheds light on banks' incentives to change prices of their retail products. Moreover, tracing bank-related differences in pricing policies is crucial in the validation of various theories.

The importance of accounting for heterogeneity in dynamic relationships is stressed in estimating persistence in the real exchange rate (e.g., Imbs et al., 2005) and inflation (e.g., Clark, forthcoming). We test and confirm that heterogeneity is also present in the relationship between bank interest rates and market rates. To provide a flavour of such heterogeneity, Fig. 1 presents the average, minimum and maximum retail interest rate for mortgages and time deposits in the Belgian banking market over most of the 1990s and the early 2000s. The plots also contain the market interest rate of equal maturity. ${ }^{1}$ While the similarities between retail bank and market interest rates over time are obvious, so are the dissimilarities over the cross-section of banks. The mark-up of mortgage rates over the market rate varies over banks from essentially zero to about two hundred basis points. The mark-down of time deposits exhibits similar variation over banks. In addition to levels, there are clear differences in dynamic behaviour. Consider, for instance, the varying degrees of persistence between the minimum and maximum interest rates of mortgages and time deposits. This paper aims to measure the time series behaviour of retail rates, while taking into account and - where possible - explain the cross-sectional heterogeneity.

Two early influential studies on interest rate pass-through are Hannan and Berger (1991) and Neumark and Sharpe (1992). Following their lead, the issue has been investigated by Cottarelli et al. (1995) and Gambacorta (2004) for Italy, Lago and Salas (2005) for Spain, Weth (2002) for Germany, Heffernan (1997, 2002) and Hofmann and Mizen (2004) for the UK and Hannan and Liang (1993) for the US. The contribution of this paper to that literature can be divided into three main parts. First, we assess the validity of the completeness hypothesis in the presence of both heterogeneity and cointegration. On the one hand, we perform tests that formally confirm the presence of heterogeneity in the dynamics of retail interest rates. In such an environment the homogeneity assumption implies biased dynamic coefficients, as shown by Pesaran and Smith (1995) or De Graeve et al. (2004) and Lago and Salas (2005) for the particular case of retail bank interest rates. On the other hand, we test and confirm cointegration between retail rates and market rates. Hence, the distribution of the long-run pass-through is unknown. Our approach simultaneously resolves these two issues in evaluating the completeness hypothesis. The methods we use originate in the "large $n$, large $T$ " panel literature. Second, we introduce asymmetry within the heterogeneous approach. We try to unify much of the existing types of non-linearity into one con-

\footnotetext{
${ }^{1}$ Comparing retail rates with market rates of equal maturity - rather than with the policy rate - separates the pass-through of marginal costs from term structure effects of policy rates. This is consistent with a microeconomic banking perspective. In terms of monetary policy transmission these comparisons of retail rates with market rates should be interpreted as being conditional on the yield curve response of policy shocks. This policyto-yield part of transmission is investigated thoroughly by, among others, Cook and Hahn (1989) and Ellingsen and Söderström (2001).
} 

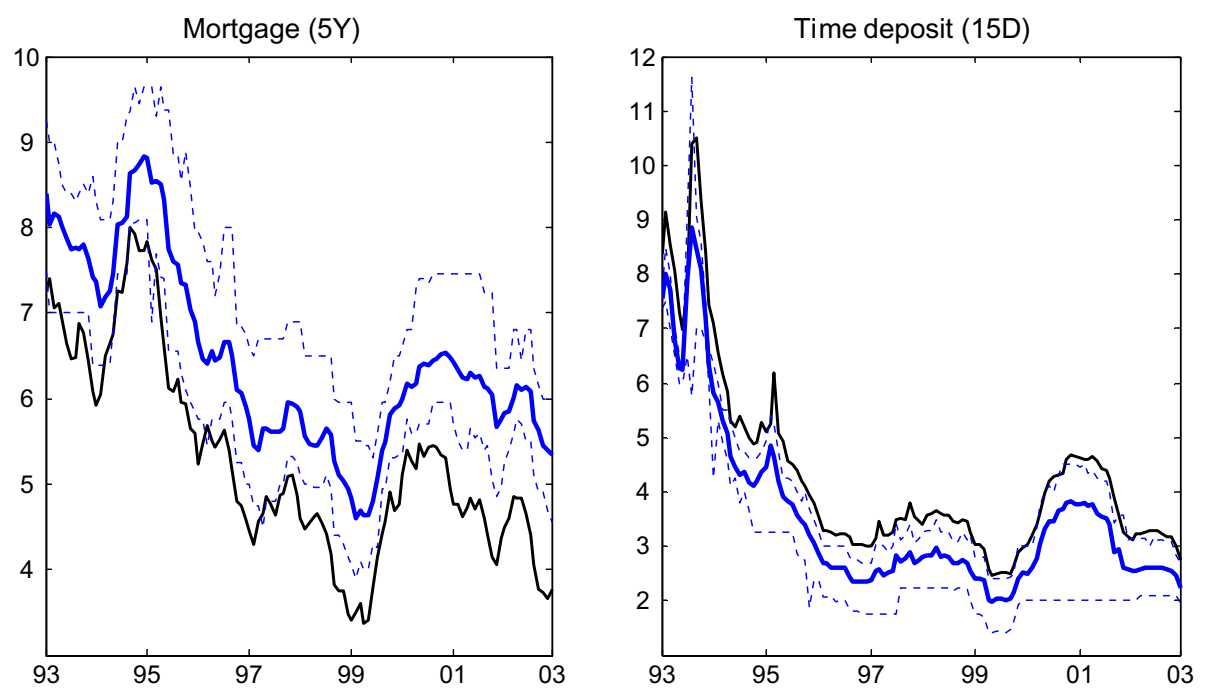

Fig. 1. Retail interest rates: mortgage and time deposit. The figure plots the evolution of the average productspecific interest rate (thick solid line) across all banks, the highest and the lowest (dashed lines) product-specific rate charged by any bank in a given month and the evolution of the market interest rate with the same maturity as the specific product (thin solid line). The titles of the charts denote the name of the product. The maturity of the corresponding market rate is reported in brackets after the product name (where $\mathrm{D}=\mathrm{day}, \mathrm{M}=\mathrm{month}$, $\mathrm{Y}=$ year).

venient but comprehensive form to allow several theories and types of asymmetry to coexist. Disaggregate evidence on various types of asymmetry is scarce, especially for EMU. Third, we analyse a total of 13 products, both loans and deposits. Existing studies typically consider only a limited number of products. The present analysis covers numerous loan and deposit products and thus a large spectrum of retail banking activities. Differences in price setting behaviour over products may well be the source of differential responses of consumption and investment to shocks hitting the economy.

In anticipation of our results, we find that heterogeneity is substantial in retail interest rates. In contrast to what homogenous studies tend to find, the incorporation of heterogeneity reveals that banks adjust their retail interest rates fast and incomplete. At the source of heterogeneity are differences in banks' financial structure and market power. Our results show that a bank with a large capital buffer or a large market share will have the tendency to charge high loan mark-ups and adjust less than complete to changing market conditions. On the bank asset side, corporate loans are priced more competitively relative to consumer products. With respect to bank liabilities, the interest rates of demand and savings deposits are very rigid, while this is far less the case for time deposits and savings bonds. We also find evidence of non-linearities. Specifically, larger deviations from equilibrium interest rates are more swiftly corrected. Moreover, while the speed of adjustment for loans is relatively symmetric, deposit interest rates tend to be more rigid upwards.

The paper is organized as follows. The second section describes the data. Section 3 introduces the heterogeneous framework and presents a first set of results. In Section 4 we investigate the scope for non-linearities. Section 5 traces the sources of heterogeneous 
pricing behaviour. A final section summarizes the main results and discusses a number of implications.

\section{Data}

The specific market we study is the Belgian banking market. The dataset comprises monthly bank-specific interest rates of 31 banks for 13 products over the period January 1993-December 2002. These banks account for more than $90 \%$ of total assets of the Belgian banking sector. The interest rates apply to new operations. The loan and deposit products are standardized in the sense that maturity, amount and debtor quality are stipulated. Loan rates in the sample are those charged to the most creditworthy borrowers. Analysing standardized products has the advantage of limiting the effects of non-price competition. Concerning deposits, we examine the behaviour of three time deposits, two savings bonds, one demand and a savings deposit. The loan products cover four corporate loans and two consumer-oriented loans. The dataset is unbalanced due to a number of mergers and acquisitions. We treat banks that were involved in a merger or acquisition as different units before the merger, and as one thereafter. As is evident from Fig. 1, over most of the sample period interest rates have been declining. This characteristic can largely be explained by the EMU-related convergence of interest rates, inflation and the stance of the business cycle and of monetary policy. The picture that emerges from the loan and deposit rates is that bank retail rates generally follow changes in market rates with a comparable maturity. However, there are clear differences across products in terms of speed and magnitude of the adjustment.

\section{Measurement}

\subsection{Methodology}

The standard approach for measuring the pass-through is an error correction framework. The way in which we treat heterogeneity and the "large $n$, large $T$ " methods ${ }^{2}$ we use are far less common. This section describes our approach and highlights where abandoning the homogeneity assumption may help. For each of the 13 products, we consider a separate panel. A first step in measuring the pass-through is determining the relevant marginal cost for each product. For the products for which a reference maturity was not explicitly specified we use as marginal cost the market rate which exhibits the highest correlation. The fact that products are standardized translates naturally into considering the same marginal cost for all banks, within a product category.

The majority of interest rate series in our dataset are non-stationary over the sample period. For modelling purposes, in order to avoid spurious results, a natural question to ask is whether the respective retail and market rates are cointegrated. Our aim is to allow heterogeneity in almost all aspects of banks' price setting behaviour. We therefore apply Pedroni's (1999) cointegration test, i.e., the between-dimension augmented

\footnotetext{
${ }^{2}$ The dimension of our dataset $(n=31, T=120)$ falls well within the range of the prototypical international macro-economic datasets, for which the "large $n$, large $T$ " methods were originally designed.
} 
Dickey-Fuller test (see also McCoskey and Kao, 1999). This residual-based test is based on individual Engle-Granger cointegrating regressions of the form:

$$
b_{i, t}=c_{1 i}+\delta_{i} m_{t}+u_{i, t},
$$

where $b=$ bank rate, $m=$ market rate, $t=1, \ldots, T$ indexes time and incorporation of heterogeneity is clear from the " $i$ " subscripts on the parameters $(i=1, \ldots, n$ where $n$ is the number of banks). Individual long-run pass-through coefficients are measured by $\delta_{i}$, while $c_{1 i}$ captures bank-specific mark-ups. The cointegration test, under the null hypothesis of no cointegration, allows for both short $\left(u_{i, t}\right)$ and long-run $\left(\delta_{i}\right)$ heterogeneity under the alternative. In case of cointegration, or stationary $u_{i, t}$, an error correction representation of the retail rate exists:

$$
\Delta b_{i, t}=c_{2 i}+\sum_{k=1}^{p} \alpha_{k i} \Delta b_{i, t-k}+\sum_{l=0}^{q} \beta_{l i} \Delta m_{t-l}+\gamma_{i} u_{i, t-1}+\varepsilon_{i, t} .
$$

The lag length $(p, q)$ is determined using the Schwarz Bayesian Information Criterion. The term $\gamma_{i} u_{i, t-1}$ captures the adjustment towards equilibrium. When $\left.\gamma_{i} \in\right]-1,0[$, this confirms the presence of an equilibrium-restoring relationship.

Even though our approach fully encompasses heterogeneity, the estimation procedure still allows observations on a macro-scale. First, aggregate coefficients $l$ (where $\left.l \in\left\{c_{1}, c_{2}, \alpha_{1}, \ldots, \alpha_{p}, \beta_{0}, \ldots, \beta_{q}, \gamma\right\}\right)$ are a weighted average of the bank-specific coefficients. The weights $w_{i}^{l}$ are a function of the respective estimated covariances (Swamy, 1970). ${ }^{3}$ Second, the average long-run pass-through, $\delta$, is estimated following Phillips and Moon (1999). They provide an estimator of the heterogeneous cointegration coefficient. ${ }^{4}$

There are a couple of differences between our estimates and more standard panel estimates (such as fixed and random effects estimators). First, consider the immediate passthrough coefficient $\beta_{0}$. Our estimator for this coefficient is $\beta_{0}=\sum_{i=1}^{N} w_{i}^{\beta_{0}} \beta_{0 i}$. This specification allows each bank to exhibit a different immediate reaction to changes in market rates. A similar relation holds for $c_{1}, c_{2}, \alpha_{1}, \ldots, \alpha_{p}, \beta_{1}, \ldots, \beta_{q}$ and $\gamma$. The traditional panel approach controls for an individual level effect (in $c_{1}$ and $c_{2}$ ), but disregards heterogeneity in the dynamics (the $\alpha, \beta$ and $\gamma$ coefficients). Second, much of the pass-through literature has focused on the speed with which banks adjust their retail rates to changing money market conditions. A commonly used metric is the "mean lag", an indicator of the number of months it takes to attain the long-run equilibrium. For an individual bank this measure can be computed as $\theta_{i}=\frac{\left|\delta_{i}-\beta_{0 i}\right|}{\left|\gamma_{i}\right|}$. The present model allows us to compute the average mean lag $\theta=\sum_{i=1}^{N} w_{i}^{\theta} \theta_{i}=\sum_{i=1}^{N} w_{i}^{\theta} \frac{\left|\delta_{i}-\beta_{0 i}\right|}{\left|\gamma_{i}\right|}$, rather than the mean lag average $\left|\sum_{i=1}^{N} w_{i}^{\delta} \delta_{i}-\sum_{i=1}^{N} w_{i}^{\beta_{0}} \beta_{0 i}\right| /\left|\sum_{i=1}^{N} w_{i}^{\gamma} \gamma_{i}\right|$. The latter is what one can extract from a standard homogenous panel. The former measures the average of individual adjustment speeds, which is in interpretation closer to the economic parameter of interest. There is a similar and equally important distinction between the average long-run pass-through, $\delta$, and the long-run average pass-through. Recently, these points have proven to be important in the

\footnotetext{
${ }^{3}$ An earlier version of the paper (De Graeve et al., 2004) compared the Swamy-estimates with mean-group estimates as suggested by Pesaran and Smith (1995). We found no substantial differences.

${ }^{4}$ In particular, when the variance of the exogenous variable is (almost surely) the same for each cross-sectional unit, as in the setup of Eq. (1), the pooled estimator proposed by Phillips and Moon (1999) traces the average long-run parameter.
} 
estimation of inflation persistence and purchasing power parity. Our results suggest that these distinctions are also important when dealing with retail interest rates. Third, a very interesting by-product of the way we estimate the average long-run pass-through is that it has a tractable normal distribution. ${ }^{5}$ This allows us to assess whether the pass-through is effectively complete $(\delta=1)$. By contrast, alternative estimators of pass-through coefficients follow non-standard distributions, leaving the completeness issue unresolved.

\subsection{Results}

Table 1 reports the cointegration and heterogeneity tests. Table 2 presents the estimation results. ${ }^{6}$ For all loans and deposits, the size and significance of the negative adjustment coefficients in column $\mathrm{V}$ of Table 2 confirm the presence of an equilibriumrestoring relationship. This is consistent with the results of the cointegration tests in Table 1. As the $t$ statistics in column III of Table 1 show, for every product panel, the null hypothesis of no cointegration is rejected. Although the cointegration test indicates the presence of a cointegrating relation in the demand deposit panel, its adjustment coefficient is only marginally significant. Conversely, in the case of trade credit cointegration is confirmed only marginally by the panel augmented Dickey-Fuller test, but its adjustment coefficient is highly significant. All other loan and deposit products are clearly cointegrated with their respective comparable market rates.

The presence of heterogeneity is also evident from Table 1. Columns IV and V of this table compare, by means of likelihood ratio tests, our model with a traditional homogenous coefficient model. For all products the likelihood ratio test rejects the null of homogeneity. Thus, the data prefer a heterogeneous specification. Not fully appreciating the amount of heterogeneity in the data may generate substantial biases, as De Graeve et al. (2004) show for the adjustment coefficient and Lago and Salas (2005) for the long-term pass-through. The importance of heterogeneity can be deduced from Table 2 . Each number in square brackets is the percentage of the standard error that is due to cross-sectional heterogeneity. The remaining proportion is mere parameter uncertainty. As these percentages typically attain values of $70 \%$ and more, most of the uncertainty surrounding our macro-estimates is clearly due to cross-sectional variation. ${ }^{7}$

\footnotetext{
${ }^{5}$ In a traditional time series setting OLS provides (super)consistent estimates of the cointegration vector. Due to the non-stationarity of the regressors, however, these estimators no longer have standard distributions. In a panel setting too, one can consistently estimate the cointegration vector by OLS. However, what is particular to "large $n$, large $T$ " panels is that certain estimators of cointegration coefficients converge to a normal distribution, as shown by Phillips and Moon (1999). This enables standard hypothesis testing on long-run coefficients.

${ }^{6}$ All results have been subjected to a number of sub-sample stability and other robustness checks. First, market rates are highly volatile in 1993 due to the EMS crisis. Performing the analysis from 1994 onward never had a significant impact on the results. Second, after the introduction of the euro the pass-through of some products is low relative to the full sample. It is difficult, however, to attribute this result solely to the introduction of the euro. It may also be driven by the more or less simultaneous consolidation of the banking sector. The results in Section 5 (in particular those for market share) suggest that at least some weight should be attributed to this latter interpretation. Additional details can be found in De Graeve et al. (2004).

7 To illustrate the potential differences in inference between various approaches, consider the average mean lag of trade credit in Table 2, which is 0.198 . This is the average of the individual mean lags and corresponds to the economic parameter of interest. The mean lag average can also be computed from the table, as $\frac{\left|\delta-\beta_{0}\right|}{|\gamma|}$. For this product this yields $\frac{|0.908-0.692|}{|-0.279|}=0.774$. For more than half the products in our sample, we obtain a mean lag average at least twice as high as the average mean lag. The largest bias is found for current account overdrafts.
} 
Table 1

Cointegration and heterogeneity tests

\begin{tabular}{|c|c|c|c|c|}
\hline \multirow[t]{2}{*}{ Products (I) } & \multicolumn{2}{|l|}{ Cointegration test } & \multicolumn{2}{|c|}{ Heterogeneity test } \\
\hline & mean (ADF) (II) & $t$ Statistics (III) & LR (IV) & Critical value $(\mathrm{V})$ \\
\hline \multicolumn{5}{|l|}{ Loans } \\
\hline Trade credit $(2 \mathrm{M})$ & -2.40 & -1.66 & 138.79 & 65.17 \\
\hline Current account overdrafts $(2 \mathrm{M})$ & -2.39 & -2.15 & 454.31 & 110.90 \\
\hline Term loan $(6 \mathrm{M})$ & -5.54 & -16.02 & 262.49 & 69.83 \\
\hline Investment loan (5Y) & -4.06 & -9.61 & 240.77 & 74.47 \\
\hline Consumer credit (3Y) & -3.05 & -5.12 & 274.73 & 83.68 \\
\hline Mortgage (5Y) & -3.30 & -7.10 & 127.01 & 101.88 \\
\hline \multicolumn{5}{|l|}{ Deposits } \\
\hline Time deposit (15D) & -4.67 & -14.79 & 777.65 & 101.88 \\
\hline Time deposit (3M) & -4.88 & -17.39 & 864.82 & 119.87 \\
\hline Time deposit (3Y) & -4.41 & -13.30 & 222.08 & 101.88 \\
\hline Savings bond (1Y) & -4.49 & -14.07 & 212.18 & 106.39 \\
\hline Savings bond (5Y) & -3.72 & -10.15 & 256.76 & 115.39 \\
\hline Savings deposit (7Y) & -2.37 & -2.01 & 238.57 & 110.90 \\
\hline Demand deposit (15Y) & -2.78 & -2.07 & 77.68 & 26.30 \\
\hline
\end{tabular}

Column I contains the name of the loan and deposit products. The maturity of the corresponding market rate is reported in brackets after the product name (where $\mathrm{D}=$ day, $\mathrm{M}=$ month, $\mathrm{Y}=$ year). The second and third columns present, respectively, the mean augmented Dickey-Fuller $t$ statistics (mean(ADF)) and corrected $t$ statistics. The performed correction is $n^{0.5} \cdot($ mean $(\mathrm{ADF})-\mu) / \sigma$ and uses $\mu=-2.026$ and $\sigma=0.82$ (see McCoskey and Kao, 1999, for further details). Columns IV and V of the table show the likelihood ratio (LR) and the corresponding 5\% Chi-square critical value. A value above the critical value indicates the restrictions of the homogenous coefficient model are not valid.

We reject the completeness hypothesis for the majority of the products in our sample. While much of the literature accepts the completeness of the long-term pass-through, our view is that it should be measured and tested differently. As regards measurement, the present estimates do not suffer from biases due to the use of aggregated data or the imposition of homogenous slopes. As regards the testing procedure, we take into account distributional aspects of the long-term pass-through estimate. More precisely, we trace the exact distribution of long-term pass-through $(\delta)$ relying on results in Phillips and Moon (1999). The evidence in column III of Table 2 reveals that the long-run response is one-for-one only for four out of 13 products. In particular, the long-term time deposit, the mortgage loan and two of the corporate loans, viz. the term and investment loan, have a long-term pass-through that is not statistically different from one. The majority of the products, however, exhibits an incomplete passthrough.

Turning to point estimates, for loans we find a considerable amount of short-term stickiness (column IV of Table 2). This is in line with the bulk of evidence in the literature. Yet substantial differences exist across the respective loan products. This stickiness is most pronounced for the consumer loans in our sample, while only to a lesser extent for corporate loans. Regarding the consumer loans, at most $40 \%$ of the long-term pass-through is adjusted on impact, whereas for corporate loans at least $75 \%$ of the final response is immediately realized. The long-run pass-through, too, is low for the two consumer-oriented products (65\% for consumer credit and $91 \%$ for mortgages) relative to equal maturity 
Table 2

Measurement

\begin{tabular}{|c|c|c|c|c|c|}
\hline \multirow[t]{2}{*}{ (I) } & (II) & (III) & (IV) & $(\mathrm{V})$ & $(\mathrm{VI})$ \\
\hline & $c_{1}$ & $\delta$ & $\beta_{0}$ & $\gamma$ & $\theta$ \\
\hline \multicolumn{6}{|l|}{ Loans } \\
\hline Trade credit $(2 \mathrm{M})$ & $\begin{array}{l}3.206^{* * *} \\
(0.185) \\
{[0.96]}\end{array}$ & $\begin{array}{l}0.908^{* * *} \\
(0.025) \\
{[0.78]}\end{array}$ & $\begin{array}{l}0.692^{* * *} \\
(0.069) \\
{[0.86]}\end{array}$ & $\begin{array}{c}-0.279^{* * *} \\
(0.089) \\
{[0.93]}\end{array}$ & 0.198 \\
\hline Current account overdrafts $(2 \mathrm{M})$ & $\begin{array}{l}4.595^{* * *} \\
(0.150) \\
{[0.93]}\end{array}$ & $\begin{array}{l}0.841^{* * *} \\
(0.032) \\
{[0.91]}\end{array}$ & $\begin{array}{l}0.635^{* * *} \\
(0.055) \\
{[0.89]}\end{array}$ & $\begin{array}{c}-0.190^{* * *} \\
(0.056) \\
{[0.92]}\end{array}$ & 0.200 \\
\hline Term loan $(6 \mathrm{M})$ & $\begin{array}{l}1.541^{* * *} \\
(0.369) \\
{[0.99]}\end{array}$ & $\begin{array}{l}0.964^{* * *} \\
(0.086) \\
{[0.97]}\end{array}$ & $\begin{array}{l}0.982^{* * *} \\
(0.092) \\
{[0.90]}\end{array}$ & $\begin{array}{c}-0.689^{* * *} \\
(0.136) \\
{[0.92]}\end{array}$ & 0.167 \\
\hline Investment loan (5Y) & $\begin{array}{l}1.855^{* * *} \\
(0.204) \\
{[0.91]}\end{array}$ & $\begin{array}{l}0.994^{* * *} \\
(0.032) \\
{[0.87]}\end{array}$ & $\begin{array}{l}0.767^{* * *} \\
(0.057) \\
{[0.71]}\end{array}$ & $\begin{array}{c}-0.337^{* * *} \\
(0.078) \\
{[0.91]}\end{array}$ & 0.404 \\
\hline Consumer credit (3Y) & $\begin{array}{l}4.579^{* * *} \\
(0.466) \\
{[0.86]}\end{array}$ & $\begin{array}{l}0.651^{* * *} \\
(0.085) \\
{[0.77]}\end{array}$ & $\begin{array}{l}0.194^{* *} \\
(0.085) \\
{[0.68]}\end{array}$ & $\begin{array}{c}-0.245^{* * *} \\
(0.047) \\
{[0.87]}\end{array}$ & 0.659 \\
\hline Mortgage (5Y) & $\begin{array}{l}1.509^{* * *} \\
(0.198) \\
{[0.91]}\end{array}$ & $\begin{array}{l}0.913^{* * *} \\
(0.066) \\
{[0.90]}\end{array}$ & $\begin{array}{l}0.355^{* * *} \\
(0.058) \\
{[0.75]}\end{array}$ & $\begin{array}{c}-0.216^{* * *} \\
(0.027) \\
{[0.67]}\end{array}$ & 1.448 \\
\hline \multicolumn{6}{|l|}{ Deposits } \\
\hline Time deposit (15D) & $\begin{array}{c}-0.184 \\
(0.115) \\
{[0.96]}\end{array}$ & $\begin{array}{l}0.890^{* * *} \\
(0.028) \\
{[0.97]}\end{array}$ & $\begin{array}{l}0.726^{* * *} \\
(0.089) \\
{[0.94]}\end{array}$ & $\begin{array}{c}-0.403^{* * *} \\
(0.085) \\
{[0.89]}\end{array}$ & 0.287 \\
\hline Time deposit (3M) & $\begin{array}{c}-0.128 \\
(0.098) \\
{[0.95]}\end{array}$ & $\begin{array}{l}0.884^{* * *} \\
(0.019) \\
{[0.95]}\end{array}$ & $\begin{array}{l}0.852^{* * *} \\
(0.069) \\
{[0.93]}\end{array}$ & $\begin{array}{c}-0.525^{* * *} \\
(0.103) \\
{[0.93]}\end{array}$ & 0.222 \\
\hline Time deposit (3Y) & $\begin{array}{c}-0.059 \\
(0.079) \\
{[0.90]}\end{array}$ & $\begin{array}{l}0.980^{* * * *} \\
(0.010) \\
{[0.77]}\end{array}$ & $\begin{array}{l}0.756^{* * *} \\
(0.039) \\
{[0.81]}\end{array}$ & $\begin{array}{c}-0.472^{* * *} \\
(0.061) \\
{[0.87]}\end{array}$ & 0.327 \\
\hline Savings bond $(1 \mathrm{Y})$ & $\begin{array}{l}0.041 \\
(0.043) \\
{[0.83]}\end{array}$ & $\begin{array}{l}0.924^{* * *} \\
(0.010) \\
{[0.81]}\end{array}$ & $\begin{array}{l}0.678^{* * *} \\
(0.032) \\
{[0.78]}\end{array}$ & $\begin{array}{c}-0.513^{* * *} \\
(0.077) \\
{[0.93]}\end{array}$ & 0.241 \\
\hline Savings bond ( $5 \mathrm{Y})$ & $\begin{array}{l}0.037 \\
(0.082) \\
{[0.91]}\end{array}$ & $\begin{array}{l}0.968^{* * *} \\
(0.012) \\
{[0.89]}\end{array}$ & $\begin{array}{l}0.735^{* * *} \\
(0.036) \\
{[0.81]}\end{array}$ & $\begin{array}{c}-0.343^{* * *} \\
(0.053) \\
{[0.85]}\end{array}$ & 0.315 \\
\hline Savings deposit (7Y) & $\begin{array}{c}-0.275 \\
(0.234) \\
{[0.89]}\end{array}$ & $\begin{array}{l}0.695^{* * *} \\
(0.029) \\
{[0.91]}\end{array}$ & $\begin{array}{l}0.022 \\
(0.034) \\
{[0.56]}\end{array}$ & $\begin{array}{c}-0.115^{* * *} \\
(0.026) \\
{[0.88]}\end{array}$ & 1.720 \\
\hline Demand deposit (15Y) & $\begin{array}{c}-1.214^{* * *} \\
(0.300) \\
{[0.84]}\end{array}$ & $\begin{array}{l}0.533^{* * *} \\
(0.042) \\
{[0.88]}\end{array}$ & $\begin{array}{l}0.090 \\
(0.069) \\
{[0.75]}\end{array}$ & $\begin{array}{c}-0.075^{*} \\
(0.04) \\
{[0.89]}\end{array}$ & 2.431 \\
\hline
\end{tabular}

Each row contains the point estimates of Eqs. (1) and (2) per (product) panel. The maturity of the corresponding market rate is reported in brackets after the product name (where $\mathrm{D}=$ day, $\mathrm{M}=$ month, $\mathrm{Y}=$ year). For each (product) panel the columns report the spread $\left(c_{1}\right)$, long-term pass-through $(\delta)$, short-term pass-through $\left(\beta_{0}\right)$, the adjustment coefficient $(\gamma)$ and the mean lag $(\theta) \cdot c_{1}\left(=\sum_{i=1}^{N} w_{i}^{c_{1}} c_{1 i}\right), \beta_{0}\left(=\sum_{i=1}^{N} w_{i}^{\beta_{0}} \beta_{0 i}\right), \gamma\left(=\sum_{i=1}^{N} w_{i}^{\gamma} \gamma_{i}\right)$ and $\theta\left(=\sum_{i=1}^{N} w_{i}^{\theta} \theta_{i}\right)$ correspond to weighted average coefficients (Swamy, 1970). The long-term pass-through $(\delta)$ corresponds to the average long-run pass-through, estimated following Phillips and Moon (1999). Standard 
Table 2 (continued)

errors (in parentheses) are reported below the point estimates. Significance at the 10\%, 5\% and $1 \%$-level is, respectively, denoted by ${ }^{*},{ }^{* *}$ and ${ }^{* * *}$. Below the standard errors, the square brackets contain the percentage of these standard errors that is due to cross-sectional heterogeneity. The remaining proportion is mere parameter uncertainty.

corporate loans. ${ }^{8}$ With respect to the speed of adjustment, computation of the mean lag reveals a similar result. Banks are slower in their adjustment to market rates for consumer-oriented products. Angeloni et al. (2003) find that the ECB's policy decisions have a stronger impact on corporate investment relative to private consumption. Our results suggest that such differential composition effects of monetary policy actions may well be due to the manner in which banks adjust their retail interest rates.

Furthermore, long-term adjustment tends to be more complete for both corporate and consumer loans the longer their maturities. For time deposits and savings bonds, too, point estimates of the long-run pass-through are higher for longer maturities. This result has not been identified in previous research due to either a lack of products to compare with, or the use of a short-term market rate, rather than one with a comparable maturity. Pass-through estimates that do not distinguish between marginal cost and term structure effects - using the short-term market rate as marginal cost - typically find the opposite: the pass-through is lower the longer the maturity of the product. Our results show that this finding is only due to the incomplete transmission of short rate movements to the entire yield curve.

The Belgian bank deposit market seems to consist of two distinct segments. The first is the market for time deposits and savings bonds, where banks seem to follow changes in market conditions quite rapidly. Table 2 shows that mean lags in this segment are very low, viz. below one month. Interestingly, the product-specific spreads for time deposits and savings bonds are insignificant and sometimes even positive, accentuating the competitiveness with which these products are priced. This contrasts sharply with the other segment, namely that of demand and savings deposits. Here, the average spreads are more negative than for time deposits and savings bonds. Adjustment is particularly sluggish for both these deposits, as indicated by their mean lags (around 2 months). Moreover, the estimated immediate pass-through is $2 \%$ for savings and $9 \%$ for demand deposits. Even in the long run, the response is far from complete ( $70 \%$ and $53 \%$, respectively).

\section{Non-linearities}

\subsection{Methodology}

Non-linearities in interest rate adjustment are compatible with numerous theoretical arguments, ranging from market structure, over informational problems, to nominal rigidities and transaction costs. Most of the existing empirical work considers the asymmetry

\footnotetext{
${ }^{8}$ The sample of the consumer credit data starts in January 1996. This warrants some caution in interpreting results for consumer credit. To investigate the effect of the shorter time span we also performed the analysis for all products for that shorter period. We then find that the pass-through is lower for all products, and that the precision of the estimates is somewhat lower, relative to the full sample results. Within this shortened sample, however, consumer credit still exhibits the lowest (long and short-term) pass-through.
} 
implied by a particular theory one at the time. Since the various theories are not mutually exclusive, we propose a functional form of the interest rate adjustment process that aims to nest all theories. We focus on asymmetries in the speed of adjustment. ${ }^{9}$ Consider the following expression for $\gamma_{i}$, the adjustment coefficient of the error correction model (2), as our baseline specification $^{10}$ :

$$
\gamma_{t}= \begin{cases}\gamma_{1}+\gamma_{2} u_{t-1}+\gamma_{3}\left(u_{t-1}\right)^{2} & \text { if } u_{t-1}<\bar{u} \\ \left(\gamma_{1}+\gamma_{1}^{+}\right)+\left(\gamma_{2}+\gamma_{2}^{+}\right) u_{t-1}+\left(\gamma_{3}+\gamma_{3}^{+}\right)\left(u_{t-1}\right)^{2} & \text { if } u_{t-1} \geqslant \bar{u}\end{cases}
$$

Eq. (3) makes the dynamic adjustment regime-dependent. Regime shifts are driven by the value of the residuals $u_{t-1}$ of the cointegration relation (1) relative to a threshold, $\bar{u}$. These residuals play an important role with respect to non-linearities. In the short run retail interest rates $\left(r_{t}\right)$ often differ from their equilibrium value $\left(c_{1}+\delta m_{t}\right)$. In what follows we label these differences $\left(u_{t}\right)$ "supermargins" to indicate temporary deviations from the long-run margin $c_{1}$. These supermargins capture the bank's incentives to change its price. First, the sign of the supermargin indicates whether the bank makes profit or loss relative to its long-run mark-up. A negative supermargin for loans may indicate an increased incentive to increase loan rates. Second, the magnitude of the supermargin can also convey important information. The larger deviations from equilibrium are, the more likely it is that incentives to change prices become more pronounced. Small deviations from equilibrium may not instigate price changes.

In the lower regime the adjustment is characterized by the coefficients $\gamma_{1}, \gamma_{2}$ and $\gamma_{3}$. The upper regime measures the adjustment based on $\gamma_{1}+\gamma_{1}^{+}, \gamma_{2}+\gamma_{2}^{+}$and $\gamma_{3}+\gamma_{3}^{+}$. While the $\gamma$ coefficients determine how the bank reacts (the shape of the adjustment coefficient), the threshold $\bar{u}$ determines when there is a change in behaviour (shift to another shape). The specification (3) captures several types of adjustment behaviour suggested by economic theory. For clarity of exposition, the description below of (3) first discusses the case where $\bar{u}=0$. That is, we start by focusing on the case where asymmetry is considered relative to the long-run equilibrium (i.e., below versus above the cointegration relation). We later generalize this to a variable threshold $\bar{u}$.

First of all, Eq. (3) nests symmetric adjustment towards equilibrium: $\gamma_{1}^{+}=\gamma_{2}=\gamma_{2}^{+}=$ $\gamma_{3}=\gamma_{3}^{+}=0$. This implies a constant adjustment coefficient of $\gamma_{1}$, irrespective of the sign and size of the supermargin. Second, the sign of the supermargin may induce different dynamic responses. The coefficient $\gamma_{1}^{+}$captures the possibility of such asymmetric reactions. Asymmetry is modelled in a similar fashion in Neumark and Sharpe (1992), Scholnick (1996), Frost and Bowden (1999), Hofmann and Mizen (2004) and Sander and Kleimeier (2004). Whenever banks have some market power they may have little incentive to adjust their retail lending rates when they are above their equilibrium value

\footnotetext{
${ }^{9}$ In principle, one could allow asymmetries in each coefficient of Eq. (2). Lim (2001) takes this approach and investigates asymmetry depending on the sign of interest rate changes. However, different theoretical models predict different factors that generate the non-linearity. This suggests to go beyond the traditional models that capture only sign asymmetries, by allowing multiple drivers of non-linearity. From an econometric point of view parsimony then dictates to restrict non-linearity to a limited number of coefficients. Because of its close correspondence to theoretical models we focus on the adjustment coefficient. This is similar to most of the existing empirical literature, e.g., Neumark and Sharpe (1992), Frost and Bowden (1999), Hofmann and Mizen (2004), Sander and Kleimeier (2004).

${ }^{10}$ While all coefficients are still heterogeneous, we drop the " $i$ " subscripts to lighten notation.
} 
$\left(r_{t}>c_{1}+\delta m_{t}\right.$ in terms of Eq. (1)). For loans, a significantly positive estimate of $\gamma_{1}^{+}$indicates that banks are slower in adjusting retail rates when their mark-up is above its equilibrium level. Such behaviour is also in accordance with downward nominal price rigidity. If, however, the market is characterized by customers with sufficiently high (absolute) demand elasticities, a policy of prolonged positive deviations from equilibrium prices would result in a severe loss of demand. This could more than offset the gain in profits due to the positive supermargin and may imply an insignificant (or even negative) $\gamma_{1}^{+}$.

Third, not only the sign but also the size of the supermargin may be a source of nonlinearity in adjustment towards equilibrium (Frost and Bowden, 1999; Hofmann and Mizen, 2004). Inclusion of $\gamma_{2}$ means adjustment towards equilibrium differs for each value of the supermargin. In the case of loans, a positive estimate for this coefficient means that $\gamma_{t}$ is highly negative in case of large negative supermargins $\left(u_{t-1} \ll 0\right)$. In other words, the higher the bank's loss relative to its equilibrium mark-up, the faster it will adjust its loan rates. As supermargins increase $\gamma_{2}>0$ implies that the speed of adjustment falls. This is equivalent to adjustment coefficients closer to zero. As another example, $\gamma_{2}>0$ and $\left(\gamma_{2}+\gamma_{2}^{+}\right)<0$ implies that larger supermargins entice faster adjustment regardless of their sign. Moreover, when $\left|\gamma_{2}\right|$ differs from $\left|\gamma_{2}+\gamma_{2}^{+}\right|$asymmetric behaviour is present. Then both the sign and size of the supermargin matter for the speed of adjustment.

Fourth, the incentives that are captured by $\gamma_{2}$ could become increasingly more important for larger deviations from equilibrium. Theories of menu and switching costs imply no or relatively weak transmission of shocks when the retail interest rate is in the vicinity of its equilibrium. These theories imply $\gamma_{3}<0$. The persistence of large gaps between the market and retail interest rates, as argued relevant by Rosen (2002), is corroborated by finding $\gamma_{3}>0$. Again, there may be reasons to suspect that the proportionality differs depending on whether the retail rate is above or below the cointegration relation. We therefore also include $\gamma_{3}^{+}$in the baseline specification.

For clarity of exposition, the above description of (3) assumed $\bar{u}=0$. Alternative scenarios are conceivable, however. A bank may, for example, only raise loan rates when its loss exceeds a menu cost. This implies that the relevant threshold $(\bar{u})$ for the residuals need not be zero. In the empirical implementation, we allow the threshold to be different from zero. ${ }^{11}$ When $\bar{u} \neq 0$ the interpretation of the $\gamma$ coefficients remains the same, only the instances in which a certain $\gamma$ applies change. Starting from (3), we perform a general-tospecific procedure to determine the optimal parsimonious model.

\subsection{Results}

The estimation results of Eq. (3) are reported in Table 3. In Fig. 2 we plot the adjustment coefficient $\gamma$ implied by the estimated coefficients of Table 3 for different values of the supermargin $u$. Both for loans and deposits adjustment coefficients are more negative the further residuals are away from the estimated threshold. This is evident from the

\footnotetext{
${ }^{11}$ We estimate the threshold $\bar{u}$ as follows. Similar to Sander and Kleimeier (2004), we specify a grid over the domain of the residuals of the cointegration relation (1), $u_{t-1}$. Every point on the grid is a candidate for $\bar{u}$. For each of these points we estimate the error correction model (2), where the adjustment towards equilibrium, $\gamma$, follows (3). For reasons of estimation precision, we require that there is at least $10 \%$ of observations on each side of the threshold. Among these models we select the one with the maximal likelihood. That model's value on the grid is our estimate of the threshold $\bar{u}$.
} 
Table 3

Non-linear adjustment

\begin{tabular}{|c|c|c|c|c|c|c|c|}
\hline \multirow[t]{2}{*}{ (I) } & (II) & (III) & (IV) & $(\mathrm{V})$ & (VI) & (VII) & (VIII) \\
\hline & $\gamma_{1}$ & $\gamma_{2}$ & $\gamma_{3}$ & $\gamma_{1}^{+}$ & $\gamma_{2}^{+}$ & $\gamma_{3}^{+}$ & $\bar{u}$ \\
\hline \multicolumn{8}{|l|}{ Loans } \\
\hline Trade credit (2M) & & $\begin{array}{l}0.611^{* * *} \\
(0.074)\end{array}$ & & & $\begin{array}{c}-1.302^{* * *} \\
(0.330)\end{array}$ & & -0.107 \\
\hline $\begin{array}{l}\text { Current account } \\
\text { overdrafts }(2 \mathrm{M})\end{array}$ & $\begin{array}{c}-0.076 \\
(0.049)\end{array}$ & & $\begin{array}{l}-0.691^{* * *} \\
(0.251)\end{array}$ & & & & \\
\hline Term loan $(6 \mathrm{M})$ & & $\begin{array}{l}2.066^{* * *} \\
(0.610)\end{array}$ & & $\begin{array}{c}-0.327^{* * *} \\
(0.099)\end{array}$ & $\begin{array}{l}-2.724^{* * *} \\
(0.663)\end{array}$ & & -0.108 \\
\hline Investment loan (5Y) & $\begin{array}{l}-0.191^{* * *} \\
(0.065)\end{array}$ & & $\begin{array}{c}-0.438^{* *} \\
(0.213)\end{array}$ & & & & \\
\hline Consumer credit (3Y) & & $\begin{array}{l}0.440^{* * *} \\
(0.124)\end{array}$ & & & $\begin{array}{l}-0.760^{* * *} \\
(0.236)\end{array}$ & & 0.164 \\
\hline Mortgage (5Y) & & & $\begin{array}{c}-0.495^{* * *} \\
(0.139)\end{array}$ & & & & \\
\hline \multicolumn{8}{|l|}{ Deposits } \\
\hline Time deposit (15D) & $\begin{array}{r}-0.196^{*} \\
(0.116)\end{array}$ & $\begin{array}{l}0.594^{* *} \\
(0.274)\end{array}$ & & & $\begin{array}{c}-1.694^{* * *} \\
(0.563)\end{array}$ & & 0.036 \\
\hline Time deposit (3M) & $\begin{array}{l}-0.429^{* * *} \\
(0.105)\end{array}$ & $\begin{array}{r}0.472^{*} \\
(0.260)\end{array}$ & & & $\begin{array}{c}-0.705 \\
(0.451)\end{array}$ & & -0.114 \\
\hline Time deposit (3Y) & & & $\begin{array}{l}-2.451^{* * *} \\
(0.472)\end{array}$ & $\begin{array}{c}-0.346^{* * *} \\
(0.073)\end{array}$ & & & 0.025 \\
\hline Savings bond (1Y) & $\begin{array}{c}-0.170^{* *} \\
(0.082)\end{array}$ & & $\begin{array}{l}-2.304^{* * *} \\
(0.532)\end{array}$ & $\begin{array}{c}-0.197^{* *} \\
(0.079)\end{array}$ & & & -0.016 \\
\hline Savings bond ( $5 \mathrm{Y})$ & & & $\begin{array}{l}-5.707^{* * *} \\
(1.689)\end{array}$ & $\begin{array}{c}-0.245^{* * *} \\
(0.055)\end{array}$ & & $\begin{array}{l}4.169^{* *} \\
(1.694)\end{array}$ & -0.091 \\
\hline Savings deposit (7Y) & & & $\begin{array}{l}-0.063^{* *} \\
(0.031)\end{array}$ & & & $\begin{array}{r}-0.316^{*} \\
(0.163)\end{array}$ & 0.283 \\
\hline Demand deposit (15Y) & $\begin{array}{c}-0.075^{* *} \\
(0.037)\end{array}$ & & & & & & \\
\hline
\end{tabular}

The table provides the estimated adjustment coefficients of the pass-through model (1) and (2), where the adjustment specification is nested within the general form of Eq. (3):

$$
\gamma_{t}= \begin{cases}\gamma_{1}+\gamma_{2} u_{t-1}+\gamma_{3}\left(u_{t-1}\right)^{2} & \text { if } u_{t-1}<\bar{u}, \\ \left(\gamma_{1}+\gamma_{1}^{+}\right)+\left(\gamma_{2}+\gamma_{2}^{+}\right) u_{t-1}+\left(\gamma_{3}+\gamma_{3}^{+}\right)\left(u_{t-1}\right)^{2} & \text { if } u_{t-1} \geqslant \bar{u} .\end{cases}
$$

Estimation of the above adjustment specification allows for a non-zero threshold. The optimal threshold is given in the last column. The maturity of the corresponding market rate is reported in brackets after the product name (where $\mathrm{D}=$ day, $\mathrm{M}=$ month, $\mathrm{Y}=$ year). Standard errors are reported in parentheses. Significance at the $10 \%, 5 \%$ and $1 \%$-level is, respectively, denoted by ${ }^{*},{ }^{* *}$ and ${ }^{* * *}$.

inverse $v$-and $u$-shapes of the implied adjustment coefficients in Fig. 2. This implies that large deviations from equilibrium are swiftly corrected. In terms of point estimates, all the models have either a positive $\gamma_{2}$ combined with a more negative $\gamma_{2}^{+}$, or a negative $\gamma_{3}$ (possibly combined with a negative $\gamma_{3}^{+}$, or a positive one, but smaller in absolute values). The finding of greater inertia in interest rates when they are close to their equilibrium level is suggestive of menu or switching costs at work. Menu cost theories predict that when the price is close but not equal to its desired level, small costs of changing prices will prevent a full equilibrium correction. Similarly, switching costs predict that small deviations from 

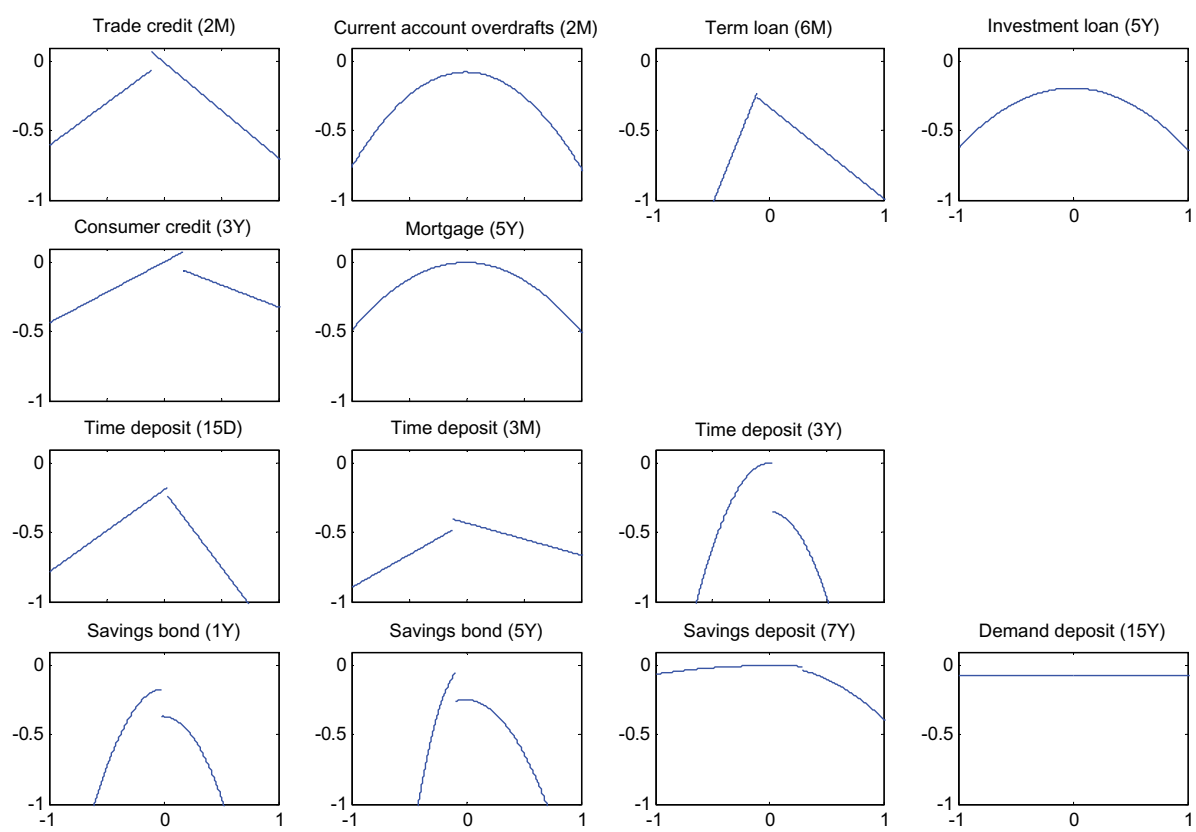

Fig. 2. Non-linear adjustment. The figure plots the implied adjustment coefficient as a function of the supermargin. The implied adjustment coefficient $(\gamma)$ is given on the $y$-axis. This is the fitted value of $\gamma$ based on estimation of Eq. (3). The estimated coefficients of this equation are reported in Table 3 . The $x$-axis contains the supermargins $u$, which are the residuals of Eq. (1). The titles of the charts denote the name of the particular product. The maturity of the corresponding market rate is reported in brackets after the product name (where $\mathrm{D}=$ day, $\mathrm{M}=$ month, $\mathrm{Y}=$ year$)$.

equilibrium will not be sufficient to make customers consider changing bank, and will thus hamper quick price changes. One type of non-linearity the data strongly reject is the persistence of large deviations from equilibrium, advocated by Rosen (2002).

Regarding the functional form in the case of loans, we find no clear asymmetric effects over products. Three of the loan products (current account overdrafts, investment loans and mortgages) exhibit a symmetric adjustment process. Only $\gamma_{1}$ and $\gamma_{3}$ are significant for these products. For trade credit and consumer credit there is a minor difference in slope depending on the sign of the residual. Only for term loans, there is a more substantial indication of asymmetry. For this product, a negative deviation from the threshold induces a faster adjustment than a positive one of equal size. In terms of Fig. 2 (first row, third graph) the adjustment coefficient is much steeper to the left of the threshold.

For six of the seven deposits, we find indications of non-linear adjustment. Moreover, four of these models imply faster adjustment at times where the deposit rate is above its equilibrium value. In particular, the adjustment of the shortest maturity time deposit is characterized by $\left|\gamma_{2}\right|<\left|\gamma_{2}+\gamma_{2}^{+}\right|$and the savings deposit has $\left|\gamma_{3}\right|<\left|\gamma_{3}+\gamma_{3}^{+}\right|$. The asymmetric behaviour of the time deposit may also be inferred from Fig. 1 . The minimum of the time deposit rate tends to incorporate decreases and often neglects increases in the market rate. The long maturity time deposit and both savings bonds have a significantly negative intercept $\left(\gamma_{1}^{+}\right)$in the upper regime. These results suggest that the type of asymmetry Neumark and Sharpe (1992) show to be important in the US is also present in some of the 
Belgian deposit markets. In general, however, the effects driven by the size of the supermargin are relatively more important than sign-induced asymmetries in the adjustment speed of both loan and deposit retail interest rates.

\section{Determinants}

\subsection{Methodology and specification}

The measurement of the pass-through in Section 3 highlights the importance of heterogeneity in banks' pricing behaviour. We now investigate if heterogeneity in the pricing measures is driven by bank-specific factors. The focus is on two particular pricing measures of interest: the spread $\left(c_{1}\right)$ and the long-term pass-through $(\delta) .{ }^{12}$ For both loans and deposits, we estimate the following relation:

$$
\left(\begin{array}{c}
c_{1 i, j} \\
\delta_{i, j}
\end{array}\right)=f\left(\begin{array}{cc}
\text { market power }_{i, j}, & \text { financial } \text { structure }_{i}, \\
\text { operational structure }_{i}, & \text { product market dummies }_{j}
\end{array}\right),
$$

where $i$ indexes individual banks and $j$ refers to the respective products. Due to heterogeneity between banks and among products, the left-hand side variables are heteroscedastic. In order to cope with this feature, we estimate Eq. (4) by (feasible) generalized least squares. The right-hand side variables are constructed from bank balance sheet and profit and loss account data. We now detail on the specific variables ${ }^{13}$ and hypotheses included.

The literature concerned with the credit channel of monetary policy transmission has stressed the importance of banks' financial structure, in particular bank capitalization and liquidity, in determining their responsiveness to monetary policy. Poorly capitalized and illiquid banks (Kashyap and Stein, 2000) are hypothesized to be relatively vulnerable to monetary, and by implication, market shocks. Moreover, banks have to maintain regulatory capital against their risk-weighted assets, implying that their capacity to expand lending depends on their capital adequacy. In line with Gambacorta and Mistrulli (2004), we measure the capital position of a bank by its excess capital-to-risk-weighted-asset ratio. As a measure of liquidity we include the ratio of the sum of cash, securities and the bank's net interbank position over total liabilities. Similar to equity, we expect liquidity to act as a buffer against market fluctuations, implying a negative effect on pass-through for both loans and deposits. ${ }^{14}$ Following the results of Maudos and Fernández de Guevara (2004) for net interest margins, we include excess capital in the spread regressions too.

\footnotetext{
${ }^{12}$ We also investigated heterogeneities in the other pricing measures, such as adjustment speed $(\gamma$ and $\theta)$ and immediate pass-through $\left(\beta_{0}\right)$, yet suppress their results. The results for adjustment speed are not very stable, especially when taking into account non-linearities. Heterogeneities in the short-term pass-through are generally driven by the same factors that influence the long-term pass-through.

13 The characteristics we consider are structural in the sense that they capture typical features of banks that do not change very much over time, such as balance sheet structure or market position. We therefore use bankspecific averages over the sample period. One instance in which such characteristics do change significantly over time, however, is the case of mergers. The fact that we treat merged banks as different units before the merger implies that this effect is taken into account in the analysis.

${ }^{14}$ Contrary to most analyses in the credit channel literature, we do not consider bank size as a separate characteristic. Both from a theoretical and an empirical perspective, bank size is usually considered to proxy for some size-related characteristics for which data are not available. We explicitly take into account the effect of these size-related factors, leaving little independent scope for bank size in the analysis. This is confirmed in a regression of the residuals of (4) on bank size, where the latter is never significant.
} 
Another obvious determinant of bank pricing behaviour is the degree of competition in the loan or deposit market. Since Berger and Hannan (1989), tests discerning between the structure-conduct-performance and efficiency hypotheses in explaining bank margins and bank profitability have attracted considerable interest in empirical banking. Market power is proxied by market share, which we calculate for each of the loan and deposit products separately. This is consistent with the relative market power hypothesis advanced by Berger (1995) which states that a bank with a large market share in a certain product market may be able to set interest rates less competitively for that particular product. A negative (positive) effect of the market share variable on the deposit spread (loan mark-up) would thus corroborate the relative market power hypothesis. The alternative hypothesis is that banks' pricing decisions are driven by the degree of their operational efficiency. The rationale is that efficient banks have the incentive to use their cost-effectiveness to post belowaverage lending rates or above-average deposit rates. We measure the degree of each bank's operational inefficiency with the cost-income ratio (e.g., Vander Vennet, 2002) and expect a positive (negative) relationship with the estimated loan (deposit) spread. These arguments may equally apply to the long-term pass-through.

Finally, similar to Gambacorta (2004), we include two variables in the loan regressions to measure possible effects of relationship lending. On the lending side, the percentage of long-term loans in total loans is intended to proxy for long-term contacts between a bank and its customers (Berger and Udell, 1992). The hypothesis is that banks engaged in relationship lending will tend to smooth market shocks for their customers by smoothing interest rates over the business cycle. We also include the ratio of deposits over the sum of deposit and non-deposit funding to verify the thesis of Berlin and Mester (1999). They suggest that banks with a stable pool of deposits, which leaves them less vulnerable to exogenous interest rate shocks, will provide more loan rate smoothing. The expected effect of relationship lending is thus negative on the pass-through. As a compensation for keeping interest rates relatively stable, the bank could earn higher loan spreads. In sum, we expect relationships to result in higher, but less volatile loan rates. With respect to deposit rates, a low ratio signals a high degree of market-based funding, and thus pricing close to the market.

\subsection{Results}

The estimation results are presented in Table $4 .{ }^{15}$ Consider the spread regressions in columns II and III. The adjusted $R^{2}$ indicates that the specification captures heterogeneity in loans very well $(80 \%)$, while less so for deposits $(13 \%)$. The good performance of the loan regression is comforting for our baseline specification. The relatively poor fit for deposit spreads is most likely due to the (statistically) zero spread of many deposit products (see Section 3, Table 2). Capital exerts a positive effect on both the loan and deposit spread. Gambacorta (2004) finds similar effects of capital on interest rate levels in the Italian banking market. In terms of excess capitalization the 25 th percentile bank has a loan mark-up that is 38 basis points lower than the mark-up of the 75th percentile bank (implied differences are reported in square brackets). Market share has a significantly

\footnotetext{
15 All regressions contain product dummies. These are not reported in the table, but are approximately equal to the spread and long-run pass-through estimates in Table 2.
} 
Table 4

Determinants of heterogeneity

\begin{tabular}{|c|c|c|c|c|c|c|c|}
\hline \multirow[t]{4}{*}{ (I) } & \multicolumn{4}{|c|}{ Dependent variable } & \multicolumn{3}{|c|}{ Summary statistics } \\
\hline & \multicolumn{2}{|l|}{ Spread } & \multicolumn{2}{|l|}{ LT PT } & \multirow[t]{2}{*}{ Mean } & \multirow[t]{2}{*}{ Std } & \multirow[t]{2}{*}{$75-25$} \\
\hline & Loans $c_{1}$ & Deposits $c_{1}$ & Loans $\delta$ & Deposits $\delta$ & & & \\
\hline & (II) & (III) & (IV) & $(\mathrm{V})$ & $(\mathrm{VI})$ & (VII) & (VII) \\
\hline \multicolumn{8}{|l|}{ Bank characteristics: } \\
\hline Liquidity & & & $\begin{array}{c}-0.20^{* *} \\
(0.08) \\
{[-0.076]}\end{array}$ & $\begin{array}{c}-0.06^{*} \\
(0.03) \\
{[-0.023]}\end{array}$ & 0.412 & 0.219 & 0.373 \\
\hline Excess capital & $\begin{array}{l}10.87^{* * *} \\
(2.34) \\
{[0.377]}\end{array}$ & $\begin{array}{l}3.18^{* * *} \\
(1.00) \\
{[0.110]}\end{array}$ & $\begin{array}{c}-1.53^{* *} \\
(0.65) \\
{[-0.053]}\end{array}$ & $\begin{array}{c}-0.46^{* *} \\
(0.18) \\
{[-0.016]}\end{array}$ & 0.0290 & 0.060 & 0.035 \\
\hline Market share & $\begin{array}{l}0.58 \\
(0.42) \\
{[0.045]}\end{array}$ & $\begin{array}{c}-0.59^{* *} \\
(0.27) \\
{[-0.046]}\end{array}$ & $\begin{array}{c}-0.21^{* * *} \\
(0.07) \\
{[-0.016]}\end{array}$ & $\begin{array}{l}0.05 \\
(0.07) \\
{[0.004]}\end{array}$ & 0.073 & 0.127 & 0.077 \\
\hline Inefficiency & $\begin{array}{c}-0.48 \\
(0.72) \\
{[-0.073]}\end{array}$ & $\begin{array}{c}-0.98^{* *} \\
(0.38) \\
{[-0.149]}\end{array}$ & $\begin{array}{l}0.19 \\
(0.12) \\
{[0.028]}\end{array}$ & $\begin{array}{l}0.21^{* * *} \\
(0.07) \\
{[0.032]}\end{array}$ & 0.257 & 0.096 & 0.152 \\
\hline $\begin{array}{l}\text { Deposits/(deposit and } \\
\text { non-deposit funding) }\end{array}$ & $\begin{array}{c}-0.52 \\
(0.69) \\
{[-0.123]}\end{array}$ & $\begin{array}{l}0.04 \\
(0.18) \\
{[0.010]}\end{array}$ & $\begin{array}{l}0.08 \\
(0.12) \\
{[0.018]}\end{array}$ & $\begin{array}{c}-0.06 \\
(0.04) \\
{[-0.014]}\end{array}$ & 0.686 & 0.158 & 0.235 \\
\hline Long-term loans/total loans & $\begin{array}{c}-0.45 \\
(0.50) \\
{[-0.138]}\end{array}$ & & $\begin{array}{l}0.07 \\
(0.08) \\
{[0.023]}\end{array}$ & & 0.714 & 0.201 & 0.304 \\
\hline Adjusted $R^{2}$ & 0.80 & 0.13 & 0.28 & 0.53 & & & \\
\hline
\end{tabular}

Column I contains the variables included in each regression. Columns II (loans) and III (deposits) contain the results of the spread regression. They report for each variable the point estimate and White-corrected standard error (in parentheses). Significance at the $10 \%, 5 \%$ and $1 \%$-level is, respectively, denoted by ${ }^{*},{ }^{* *}$ and ${ }^{* * *}$. The square brackets contain the implied difference for each variable between the 75 th and 25 th percentile bank, computed as the point estimate times the interquartile range. Columns IV (loans) and V (deposits) report the same information for the long-term pass-through (LT PT) regression. Additionally, the right-hand panel provides the mean (column VI), the standard deviation (column VII, std) and the interquartile range (column VIII, 75th25 th percentile) per bank characteristic. The last row presents the adjusted $R^{2}$ of each regression.

negative (positive) effect on deposit (loan) spreads. ${ }^{16}$ This finding corroborates the relative market power hypothesis of Berger (1995): having a large market share in the respective markets allows banks to charge high loan rates and pay low deposit rates. In addition, the deposit spread is significantly negatively affected by the inefficiency indicator. This is consistent with the findings of Focarelli and Panetta (2003) for Italy. There too, efficient banks pass on part of their cost-effectiveness onto consumers in the form of higher deposit rates. The two proxies for relationship lending are never significant. ${ }^{17}$

\footnotetext{
${ }^{16}$ For loans, the effect is positive and insignificant in the baseline specification. However, dropping the most insignificant variables, we find a coefficient of 0.738 for market share, with a standard error of 0.368 .

17 We also included the long-term business variable in the deposit regressions. It is never significant and does not affect the obtained results. Another variable that does not appear influential to our results is credit risk. In contrast to e.g., Gambacorta (2004), we find that it does not affect our loan pricing measures. This is probably due to the fact that the products in our sample are those provided to the most creditworthy customers.
} 
Turning to the long-term pass-through regressions, the baseline specification explains $28 \%$ of heterogeneity in loans and $53 \%$ for deposits. Heterogeneity in the dynamics of retail rates is for a large part driven by capitalization and liquidity. Liquid and highly capitalized banks have a lower pass-through, both for loans and deposits. In other words, the pricing behaviour of these banks is least tied to market developments. The implied differences suggest that the effect of liquidity on the loan pass-through is large, even relative to the already substantial effect of capitalization. This supports one of the basic hypotheses underlying the bank lending channel of monetary policy transmission, viz. there are crosssectional differences in the ability of banks to shield their loan supply from market fluctuations (e.g., Kashyap and Stein, 2000).

Inefficiency has a positive effect on the pass-through, although only marginally for loans. Efficient banks are tied less closely to market conditions. Market share does not affect the deposit pass-through. Loan pass-through, by contrast, is the lowest for banks with large market shares. At first sight, the economic significance, measured by the implied difference in pass-through between the 25 th and 75 th percentile bank, seems rather small $(-0.016)$. The distribution of market shares is, however, highly skewed, indicating that market power is concentrated in a few banks. The implied difference in pass-through between the 25th percentile and the bank with the largest market share is approximately five times as large. The significantly negative effect of market share on long-term passthrough has interesting macro-economic consequences. In particular, for most of the products in the sample, we reject the completeness of the long-term pass-through coefficient $\delta$. The negative impact of market share on $\delta$ implies that the average long-run coefficient tends to be even lower for the major Belgian banks. ${ }^{18}$

\section{Conclusion}

Our analysis is concerned with the static and dynamic characteristics of retail bank interest rates. The particular market under consideration is the Belgian retail bank market. A first conclusion of the paper is that retail pricing behaviour is characterized by a substantial degree of heterogeneity. To some extent, such bank-level differences in pricing are the consequence of market power and bank lending channel effects. On the one hand, we find that banks with the largest market shares price their products least competitively, which is supportive of Berger's (1995) relative market power hypothesis. On the other hand, both loan and deposit prices of well capitalized and highly liquid banks are least responsive to changing market conditions, as predicted by the bank lending channel.

Second, for the majority of products in our sample we find that the pass-through is incomplete in the long run. This conclusion is opposite to many earlier studies (see e.g., the overview in De Bondt, 2002). Our analysis provides two methodological improvements relative to that literature, however. The first is that we take into account the non-standard distribution of the long-run pass-through. The second improvement is that the point estimates on which we base our conclusions are consistent with heterogeneity at the microlevel. The finding of incompleteness is reassuring for theoretical banking models that

\footnotetext{
${ }^{18}$ While we measure market share for each product market separately, the largest banks tend to dominate each individual segment. When computing the average pass-through for the three largest Belgian banks (which comprise, on average, $65 \%$ of total assets), it seems that large banks are prone to lower, rather than higher passthrough behaviour.
} 
incorporate non-competitive pricing. With respect to empirical analysis, our results suggest that the incorporation of heterogeneity is important in the quantification of aggregate effects.

Third, while the adjustment of loans tends to be symmetric, there is some evidence that deposit rates adjust faster downward than upward. Our non-linear analysis of adjustment speed suggests, however, that this kind of sign asymmetries is only of secondary importance. The dominant effects are size-driven for both loans and deposits. We find much faster reactions of banks' retail interest rates in case of large deviations from equilibrium mark-ups, regardless of their sign. This type of behaviour is consistent with theories of menu and switching costs. Since we find such non-linearities for 12 out of the 13 products we analyse, this seems to be a quite general feature of retail interest rates.

Finally, we uncover a number of product-related differences in pricing behaviour. On the liability side, contrary to term deposits and savings bonds, demand and savings deposits have the largest mark-downs and are least responsive to changes in marginal costs. On the asset side, corporate loans adjust both quicker and more complete to changes in money market rates with a comparable maturity, relative to consumer loans.

Although our approach is applied to the Belgian banking market, some of these results may pertain to retail interest rate analysis more generally. In view of this, it remains to be investigated to what extent heterogeneity is important in the assessment of pricing behaviour for other banking markets. Our approach can easily be applied to bank-level data for other countries. Importantly, the apparent effects of heterogeneity for at least some markets may require to re-evaluate cross-country comparisons. From a methodological point of view, interesting extensions of our approach may explicitly take into account correlations over banks for a given product (market structure), over products for a given bank (cross-subsidization), or both.

\section{Acknowledgements}

We thank Lieven Baele, Lieven Baert, Gabe de Bondt, Hans Degryse, Gerdie Everaert, Catherine Fuss, Janet Mitchell, Philip Molyneux, Peter Pedroni, Gert Peersman, José Peydro-Alcalde, Koen Schoors, Thierry Timmermans, Kostas Tsatsaronis, Raf Wouters, two anonymous referees and participants at the National Bank of Belgium (NBB) 2004 Conference on "Efficiency and Stability in an Evolving Financial System" for helpful comments and discussions. We are grateful to the NBB for providing the data used in this paper as well as financial support. De Graeve acknowledges support from F.W.O.-Vlaanderen (G.0001.02). De Jonghe is Research Assistant of the Fund for Scientific Research Flanders (F.W.O.-Vlaanderen). Vander Vennet acknowledges support from the Programme on Interuniversity Poles of Attraction Contract No. P5/2.

\section{References}

Angeloni, I., Kashyap, A.K., Mojon, B., Terlizzese, D., 2003. The output composition puzzle: A difference in the monetary transmission mechanism in the euro area and US. Journal of Money, Credit and Banking 35, 12651306.

Berger, A.N., 1995. The profit-structure relationship in banking: Tests of market-power and efficient-structure hypotheses. Journal of Money, Credit and Banking 27, 404-431.

Berger, A.N., Hannan, T.H., 1989. The price-concentration relationship in banking. Review of Economics and Statistics 71, 291-299. 
Berger, A.N., Udell, G.F., 1992. Some evidence on the empirical significance of credit rationing. Journal of Political Economy 100, 1047-1077.

Berlin, M., Mester, L.J., 1999. Deposits and relationship lending. Review of Financial Studies 12, 579-607.

Clark, T., forthcoming. Disaggregate evidence on the persistence of consumer price inflation, Journal of Applied Econometrics.

Cook, T., Hahn, T., 1989. The effect of changes in the federal funds rate target on market interest rates in the 1970s. Journal of Monetary Economics 24, 331-351.

Cottarelli, C., Ferri, G., Generale, A., 1995. Bank lending rates and financial structure in Italy. IMF Staff Papers 42, 670-700.

De Bondt, G., 2002. Retail bank interest rate pass-through: New evidence at the euro area level. ECB Working Paper, No. 136.

De Graeve, F., De Jonghe, O., Vander Vennet, R., 2004. The determinants of pass-through of market conditions to bank retail interest rates in Belgium. NBB Working Paper, No. 47.

Ellingsen, T., Söderström, U., 2001. Monetary policy and market interest rates. American Economic Review 91, 1594-1607.

Focarelli, D., Panetta, F., 2003. Are mergers beneficial to consumers? Evidence from the market for bank deposits. American Economic Review 93, 1152-1172.

Frost, D., Bowden, R., 1999. An asymmetry generator for error-correction mechanisms, with application to bank mortgage-rate dynamics. Journal of Business and Economic Statistics 17, 253-263.

Gambacorta, L., 2004. How do banks set interest rates? NBER Working Paper, No. 10295.

Gambacorta, L., Mistrulli, P., 2004. Does Bank Capital Affect Lending Behavior? Journal of Financial Intermediation 13, 436-457.

Hannan, T.H., Berger, A.N., 1991. The rigidity of prices: Evidence from the banking industry. American Economic Review 81, 938-945.

Hannan, T.H., Liang, J.N., 1993. Inferring market power from time-series data: The case of the banking firm. International Journal of Industrial Organization 11, 205-218.

Heffernan, S., 1997. Modelling British interest rate adjustment: An error correction approach. Economica 64, 211-231.

Heffernan, S., 2002. How do UK financial institutions really price their banking products? Journal of Banking and Finance 26, 1997-2016.

Hofmann, B., Mizen, P., 2004. Interest rate pass-through and monetary transmission: Evidence from individual financial institutions' retail rates. Economica 71, 99-123.

Imbs, J., Mumtaz, H., Ravn, M.O., Rey, H., 2005. PPP strikes back: Aggregation and the real exchange rate. Quarterly Journal of Economics 120, 1-44.

Kashyap, A.K., Stein, J., 2000. What do a million observations on banks say about the transmission of monetary policy? American Economic Review 90, 407-428.

Lago, R., Salas, V., 2005. Market power and bank interest rate adjustments. Banco de Espana Working Paper, No. 0539 .

Lim, G.C., 2001. Bank interest rate adjustments: Are they asymmetric? Economic Record 77, 135-147.

Maudos, J., Fernández de Guevara, J., 2004. Factors explaining the interest margin in the banking sectors of the European Union. Journal of Banking and Finance 28, 2259-2281.

McCoskey, S., Kao, C., 1999. Comparing panel data cointegration tests with an application to the "twin deficits" problem. Mimeo.

Neumark, D., Sharpe, S.A., 1992. Market structure and the nature of price rigidity: Evidence from the market of consumer deposits. Quarterly Journal of Economics 107, 657-680.

Pedroni, P., 1999. Critical values for cointegration tests in heterogeneous panels with multiple regressors. Oxford Bulletin of Economics and Statistics 61, 607-629.

Pesaran, M.H., Smith, R.P., 1995. Estimating long-run relationships from dynamic heterogeneous panels. Journal of Econometrics 68, 79-113.

Phillips, P.C.B., Moon, H.R., 1999. Linear regression limit theory for nonstationary panel data. Econometrica 67, 1057-1111.

Rosen, R.J., 2002. What goes up must come down? Asymmetries and persistence in bank deposit rates. Journal of Financial Services Research 21, 173-193.

Sander, H., Kleimeier, S., 2004. Convergence in eurozone retail banking? What interest rate pass-through tells us about monetary policy transmission, competition and integration. Journal of International Money and Finance 23, 461-492. 
Scholnick, B., 1996. Asymmetric adjustment of commercial bank interest rates: Evidence from Malaysia and Singapore. Journal of International Money and Finance 15, 485-496.

Swamy, P.A.V.B., 1970. Efficient inference in a random coefficient regression model. Econometrica 38, 311-323.

Vander Vennet, R., 2002. Cost and profit efficiency of financial conglomerates and universal banks in Europe. Journal of Money, Credit and Banking 34, 254-282.

Weth, M.A., 2002. The pass-through from market interest rates to bank lending rates in Germany. Deutsche Bundesbank Discussion Paper No. 11. 